慶應義塾大学学術情報リポジトリ

Keio Associated Repository of Academic resouces

\begin{tabular}{|c|l|}
\hline Title & Transplantation of Human Neural Stem Cells for Spinal Cord Injury in Primates. \\
\hline Sub Title & サル脊䯣損傷に対するヒト神経幹細胞移植の有効性 \\
\hline Author & 岩波, 明生(Iwanami, Akio) \\
\hline Publisher & 慶應医学会 \\
\hline Publication year & 2005 \\
\hline Jtitle & 慶應医学 (Journal of the Keio Medical Society). Vol.82, No.2 (2005. 6),p.14- \\
\hline JaLC DOI & \\
\hline Abstract & \\
\hline Notes & 号外 \\
\hline Genre & Journal Article \\
\hline URL & https://koara.lib.keio.ac.jp/xoonips/modules/xoonips/detail.php?koara_id=AN00069296-2005060 \\
& 2-0014 \\
\hline
\end{tabular}

慶應義塾大学学術情報リポジトリ(KOARA)に掲載されているコンテンッの著作権は、それぞれの著作者、学会または出版社/発行者に帰属し、その権利は著作権法によって 保護されています。引用にあたっては、著作権法を遵守してご利用ください。

The copyrights of content available on the KeiO Associated Repository of Academic resources (KOARA) belong to the respective authors, academic societies, or publishers/issuers, and these rights are protected by the Japanese Copyright Act. When quoting the content, please follow the Japanese copyright act. 


\section{Transplantation of Human Neural Stem Cells for Spinal Cord Injury in Primates.}

（サル脊䯣損傷に対するヒト神経幹細胞移植の有効性）

\section{岩 波明生}

\section{内容の要旨}

近年の神経科学、特に幹細胞生物学の目覚ましい進歩により、これ まで不可能と考えられていた損傷脊咀の再生が現実味を帯びてきて いる。既にわれわれは新生及び成体ラット脊髄損傷に対するラット神 経幹細胞移植を行い、その有効性を報告した。しかし、埇茵類と霊長 類では神経機能解剖学的にかなりの隔たりがあるため、ヒトと同じ霊 長類を用いた前臨床試験が必須である。そこで本研究の目的は、サル 損傷脊髄に対するヒト神経幹細胞移植を行い、その有効性を明らかに することである。

まず、成体コモンマーモセット10匹に対して、全身麻疩下に独自に 開発した装置を用いて、17gの重錘を50mmの高さから第 5 頚㖪レベル の硬膜上に落下させて頝㵦不全圧挫損傷モデルを作製した。即ち損傷 後急性期には重度の四肢麻㾝を呈し、その後下肢機能は徐々に回復 し、最終的には上肢優位の四肢麻㾝が残存する䅡髄不全損傷モデルで ある。次に損傷脊㵦内の微小環境を考慮して、損傷後 9 日目にBrdUで 標識したヒト胎児脊髄由来神経幹細胞を損傷脊髄内に約 $1 \times 10^{6}$ 個移 植した（移植群）。対照群では培養液のみを損傷脊髄内に注入した。 脊髄損傷および移植後にMRIを撮影し損傷部の経時的変化を調心゙、移 植後 8 週に組織学的検討を行った。また、運動機能評価としては上肢 筋力を測定するためにBar Grip test と、3 次元自発運動量を測定するた めに赤外線センサーによる24時間モニタリングを独自に開発し、損傷 前から移植後 8 週まで毎日行い 2 群間で比較検討した。

MRIでサル損傷脊髄は、急性期にはT1強調像で等信号、T2強調像で びまん性の高信号を呈し、経過とともにT1強調像で低信号、T2強調像 で高信号の境界明瞭な領域に限局化した。同信号部位は組織学的には 空洞とその周囲のグリア疲痕であった。神経幹細胞移植によりこの空 洞は縮小していた。また、免度組織染色で空洞周囲にBrdU陽性の移植 細胞を多数認め、各マーカーとの 2 重染色でNeuron, Astrocyte, Oligodendrocyteに分化していた。さらにBar grip testと自発運動量計測 のいずれにおいても、移植群が対照群よりも有意に良好な機能回復が 認められた。機能回復メカニズムに関しては、移植細胞由来のニュー ロンとホスト軸索とのシナプス形成、移植細胞由来のOligodendrocyte による再㖪鞘化、移植細胞からの神経栄養因子などが考えられる。本 研究の結果は、霊長類脊㵦損傷に対するヒト神経幹細胞移植の有効性 を示唆するものであり、神経幹細胞移植の臨床応用に向けた大きな一 歩と考えている。

\section{論文審査の要旨}

近年の幹細胞生物学の進歩により、今まで不可能とされていた損 傷脊髄の再生が現実味を帯びてきた。我々は成体ラット脊㵦損傷に 対するラット神経幹細胞移植の有効性を報告したが、䛚歯類と霊長 類では神経解剖学的にも隔たりがあるため、本治療を臨床応用する にあたってはヒトと同じ霊長類を用いた前臨床試験が必須である。 そこで本研究の目的は、サル損傷脊㕼に対するヒト神経幹細胞移植 の有効性を明らかにすることである。まず、成体コモンマーモセッ ト10匹に対して定量的な頚髄圧挫損傷を作製し、損傷後 9 日目に BrdUで標識したヒト胎児神経幹細胞を損傷脊髄内に約 $1 \times 10^{6}$ 個移植 した（移植群）。対照群では培養液のみを注入した。損傷後・移植 後にMRIを撮影し損傷部の経時的変化を調べ、移植後 8 週に組織学 的検討を行った。運動機能評価は上肢筋力を测定するBar grip test と、赤外線センサーによる自発運動量モニタリングを独自に開発 し、2 群間で比較検討した。MRIで損傷脊髄は、ヒトと同様にT1強 調像で低信号、T2強調像で高信号の境界明瞭な領域に限局化した。 同部位は組織学的には空洞とその周囲のグリア癞痕であったが、移 植群では空洞は縮小傾向にあった。免度組織染色で空洞周囲にBrdU 陽性の移植細胞を多数認め、各マーカーとの 2 重染色でNeuron, Astrocyte, Oligodendrocyteへの分化を確認した。Bar grip testと自発運 動量計測の両方で、移植群が対照群よりも有意な機能回復を認め た。

審査では、脊髄損傷を定量的に作製しても炎症の程度や回復には 個体差があるのでは、との質問がなされた。これに対して、実際に 個体差はすべてのin vivo実験に存在するがnを増やし統計学的解析を 行うことで影響を減らせると回答された。また、損傷脊剈迶内の血流 動態の変化について質問され、文献的には觢歯類で損傷後新生血管 は発現するも約 2 週間でastrocyteの遊走とともに退縮してしまうとの 報告があり、損傷部中心の血管新生を促進すれば移植細胞の生着率 の上昇や空洞の減少に寄与できるのではないかと回答された。次 に、移植により空洞が縮小したのはどの細胞によるのかとの質問が なされ、生着した移植細胞そのものもあるが、移植の効果で 2 次損 傷を免れた正常組織が残存した可能性も高いとの推察が述べられ た。さらに、Oligodendrocyteに分化した移植細胞は再髄鞘化したの かとの質問に対しては、未検討であり今後の課題であると回答され た。

以上のように、本研究は未だ検討されるべき点を残しているもの の、脊㖪損傷に対する神経幹細胞移植療法の効果を霊長類モデルで 証明することによって、臨床応用に一歩近づけたという点で有意義 であると評価された。

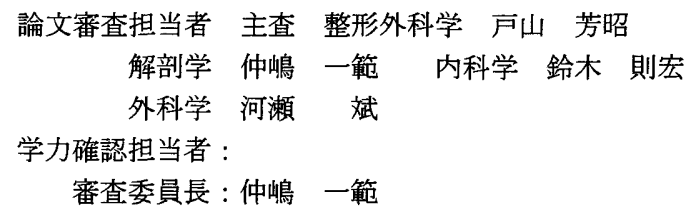

試問日：平成17年 2 月 18 日 